\title{
Pengaruh Umur Pemindahan Serta Jumlah Bibit pada Pertumbuhan dan Hasil Tanaman Padi (Oriza sativa L.)
}

\author{
Kun Rawan Sari,Umar Battong, dan Ardi Sukiman*
}

STIPER Muhammadiyah Tanah Grogot Kabupaten Paser (Kal-Tim)

Jln. Pangeran Menteri no. 96, Tlp/Hp. 081355382922, Tanah Grogot.

e-mail : battongumar@yahoo.co.id

\begin{abstract}
Abstrak
Uji Pengaruh Umur Pemindahan Serta Jumlah Bibit pada Pertumbuhan dan Hasil Tanaman Padi (Oriza sativa L.) Tahun 2019. Penelitian ini bertujuan untuk mengetahui Umur Pemindahan dan Jumlah Bibit Serta Intraksinya Terhadap Pertumbuhan dan Hasil Tanaman Padi. Di laksanakan di Desa Pepara Kecamatan Tanah Grorot Kabupaten Paser Pada Tanggal 27 September 2018 Sampai 24 Januari 2019. Dengan menggunakan Rancangan Acak Kelompok (RAK) dua factor Yaitu Berbagai Umur Pemindahan terdiri tiga taraf yaitu Umur Pemindahan umur 7 hari (w1), umur 14 hari (w2) dan 21 hari (w3) sebagai faktor pertama dan Jumlah Bibit terdiri tiga taraf yaitu diantaranya 1 bibit (j1), 2 bibit (j2) dan 3 bibit (j3) sebagai faktor kedua. Hasil penelitian menunjukkan bahwa Umur Pemindahan (W) berpengaruh tidak nyata pada semua parameter, sedangkan perlakuan Jumlah Bibit (J) berpengaruh sangat nyata pada pengamatan jumlah anakan padi pada umur 2, 4 minggu setelah tanam dan berat 1000 biji gabah. Interaksi terhadap perlakuan umur pemindahan dan jumlah bibit berpengaruh tidak nyata pada semua parameter pengamatan dari tinggi tanaman hingga akhir pengamatan berat 1000 biji gabah.
\end{abstract}

Keywords : media ember, umur pemidahan, padi sawah

\section{Pendahuluan}

Padi adalah salah satu bahan makanan yang menjadi sumber energi. Nilai gizi/energi yang diperlukan oleh setiap orang dewasa adalah 1821 kalori. Apabila kebutuhan beras tersebut di setarakan dengan beras, maka setiap hari diperlukan beras sebanyak $0,88 \mathrm{~kg}$. Di samping itu beras mengandung beberapa unsur mineral, antara lain kalsium, magnesium, sodium, fosofor, dan sebagainya (Ina Hasanah, 2007).

Konsumsi beras $113 \mathrm{~kg} /$ kapita / tahun dengan kebutuhan beras di kabupaten paser sebanyak 29.640,01 ton/tahun. Kebutuhan tanaman padi terus meningkat seiring dengan bertambahnya jumlah penduduk. Produksi padi di kabupaten pada tahun 2016 adalah sebesar 31.556 ton sedangkan tahun 2017 adalah sebesar 35.957 ton dalam pertahun jadi produksi padi dari 2016 sampai 2017 terus meningkat (Dinas Pertanian Kabupaten Paser, 2017).

Upaya peningkatan produksi padi terus dilakukan pengenalan inovasi teknologi. Salah satu faktor terpenting yang menentukan tinggi rendahnya produksi padi adalah mutu benih baik serta umur bibit yang sesuai. Umur bibit sangat menentukan jumlah anakan per rumpun sehingga akan membentukan anakan produktifnya lebih banyak. Upaya meningkatkan produksi padi dan pendapatan petani dengan penggunaan metode proporsional umur bibit dan jumlah bibit yang ditanam per lubang tanam. Penggunaan umur bibit yang masih muda sangat beresiko karena masih lemah dan perakaran yang belum kuat namun berpotensi anakan dan pertumbuhan tanaman yang tinggi, sedangkan umur bibit yang jauh lebih tua akan menurunkan produksi (Muhammad Amin, 2015). Hal ini berbanding terbalik dengan metode yang digunakan oleh petani yang menanam 4-7 bibit per lubang tanam. Para petani beralasan bahwa dengan menanam lebih banyak bibit akan meningkatkan jumlah anakan per rumpun. Oleh sebab itu perlunya penelitian lebih lanjut tentang jumlah tanam per lubang tanam.

Dalam penelitian tersebut penanaman padi yang menggunakan media ember dengan perlakuan umur pindah dan jumlah bibit yang lebih sedikit mampu memberikan hasil panen yang jauh lebih tinggi dari pada metode tradisional. Penelitian ini juga sejalan dengan metode SRI (System Rice off Intensification) yang menggunakan metode pemindahan umur bibit yang muda dan jumlah bibit memberikan jumlah anakan lebih banyak bila dibandingkan dengan penanaman konvensional 5,7 bahkan 20 bibit per lubang (Mubiar Perwasasmita dan Alik Sutaryat, 2012).

Untuk meningkatkan hasil dan pertumbuhan yang signifikan pada tanaman padi perlu adanya kegiatan penelitian yang berjudul "Uji Pengaruh Umur Pemindahan Serta Jumlah Bibit Pada Pertumbuhan dan Hasil Tanaman Padi (Oriza sativa L.).

\section{Metodologi}

Penelitian ini dilakukan selama 4 bulan dari penyemaian hingga panen yakni mulai tanggal 27 September 2018 sampai 24 Januari 2019 lokasi penelitian yaitu bertempat di Desa Pepara, Kacamatan Tanah Grogot Kabupaten Paser. Dengan ketinggian tempat 100-150 mdpl. Jenis tanah topsoil dan tekstur lempung berpasir, tipe iklim hujan tropis dengan suhu $29-34{ }^{\circ} \mathrm{C}$ dan curah hujan rata-rata saat penelitian $132.25 \mathrm{~mm} /$ bulan. Bahanbahan yang di butuhkan pada penelitian ini adalah tanah, 
Benih Varietas Mikongga, pupuk urea, $\mathrm{KCl}, \mathrm{SP}-36$, pupuk kandang kambing, insektisida BASSA, jaring burung. Alat yang dibutuhkan dalam penelitian ini adalah patak kayu, plan perlakuan, sprayer, cangkul, parang, meteran, ember, alat tulis, meteran, timbangan, kolkulator, dokumentasi menggunakan kamera hp dan mounster tester.

Rancangan yang digunakan dalam percobaan ini adalah rancangan acak kelompok (RAK) rancangan yang di susun dua faktorial yang terdiri dari :

Faktor pertama yang penggunaan umur bibit (W) yaitu terdiri dari tiga taraf yaitu:

w $1=7$ hari setelah semai

$\mathrm{w} 2=14$ hari setelah semai

w3 $=21$ hari setelah semai

Faktor kedua yang penggunaan jumlah bibit (J) yaitu terdiri tiga taraf di antaranya

$\mathrm{j} 1=1$ bibit

$\mathrm{j} 2=2$ bibit

j3 $=3$ bibit

Kombinasi perlakuan kedua faktor yaitu :

Tabel 1. Kombinasi perlakuan umur pemindahan serta jumlah bibit terhadap pertumbuhan dan hasil tanaman padi.

\begin{tabular}{cccc}
\hline \multirow{2}{*}{$\begin{array}{c}\text { Umur } \\
\text { Pemindahan }\end{array}$} & \multicolumn{3}{c}{ Jumlah Bibit ( J ) } \\
\cline { 2 - 4 } ( W $)$ & $\mathrm{j} 1$ & $\mathrm{j} 2$ & $\mathrm{j} 3$ \\
\hline w1 & $w 1 \mathrm{j} 1$ & $w 1 \mathrm{j} 2$ & $w 1 j 3$ \\
w2 & $w 2 \mathrm{j} 1$ & $w 2 \mathrm{j} 2$ & $w 2 j 3$ \\
w3 & $w 3 j 1$ & $w 3 j 2$ & $w 3 j 3$ \\
\hline
\end{tabular}

Terdapat 9 kombinasi perlakuan dengan 3 ulangan maka terdapat 27 unit perlakuan dan di setiap media ember terdapat 1 rumpun, satu perlakuan terdapat 4 populasi tanaman dengan jumlah tanaman terdapat $27 \times 4=108$ popolasi tanaman.

Untuk mengetahui pengaruh umur pemindahan dan jumlah bibit terhadap pertumbuhan tanaman padi maka data yang diperoleh dianalisa dengan menggunakan sidik ragam. Jika $\mathrm{F}$ hitung lebih besar dari $\mathrm{F}$ tabel ( 0,05 dan 0,01 ) maka dilakukan uji lanjut dengan menggunakan BNT taraf 0,05 .

\section{Hasil dan Pembahasan}

\subsection{Uji Pengaruh Umur Pemindahan Pada Pertumbuhan dan Hasil Tanaman Padi}

Berdasarkan sidik ragam perlakuan umur pemindahan (W) tidak berpengaruh nyata pada pengukuran tinggi tanaman padi pada umur 2, 4 dan 6 minggu setelah tanam, jumlah anakan total umur 2, 4 dan 6 minggu setelah tanam, Rata-rata jumlah cabang malai perumpun, rata-rata panjang malai, rata-rata jumlah gabah isi permalai, rata-rata jumlah gabah hampa permalai, ratarata jumlah gabah permalai, rata-rata berat gabah basah perumpun dan rata-rata berat gabah kering giling dan ratarata berat per 1000 biji gabah. walaupun pengamatan berpengaruh tidak nyata tetapi pengamatan pada pase vegetatif yang lebih uggul yaitu pada umur 14 hari setelah Tanam dan pada fase generatif yaitu pada umur 7 hari lebih unggul Karena pada fese pertumbuhan umur bibit mudah masih mampu untuk membentuk anakan dan pertumbuhannya sehingga pada perlakuan lainnya tidak berbeda jauh dengan perlakuan umur lainnya. Di sebabkan oleh Faktor genetik dari tanaman serta faktor dari serangan hama (lingkungan) lebih berpengaruh terhadap pertumbuhan dan produksi sehingga tanaman tidak mampu untuk menunjukkan pengaruhnya dan perbedaannya dengan perlakuan lainnya.

Jumlah cabang malai perumpun yang banyak selain ditentukan oleh suatu varietas juga dipengaruhi oleh jarak tanam atau ruang lingkup tempat tumbuh suatu tanaman. Semakin lama bibit berada di persemaian, diperkirakan pertumbuhan akar akan tetap berlangsung dan semakin memanjang. Pada saat pindah tanam kondisi sistem perakaran bisa mengalami kerusakan dan berpeluang besar bibit mengalami pertumbuhan yang tidak maksimal, karena fungsi akar sebagai penyerapan air dan unsur hara terganggu, (Tabel 2).

Tabel 2. Pengaruh Umur Pemindahan dan Jumlah Bibit Terhadap Rata-rata Jumlah Anakan Total (rumpun) Tanaman Padi 2 MST

\begin{tabular}{|c|c|c|c|c|}
\hline \multirow{2}{*}{$\begin{array}{c}\text { Umur } \\
\text { Pemindahan } \\
(\mathrm{W})\end{array}$} & \multicolumn{3}{|c|}{ jumlah Bibit ( J ) } & \multirow{2}{*}{$\begin{array}{l}\text { Rata } \\
\text { rata }\end{array}$} \\
\hline & $\begin{array}{c}\mathrm{j} 1 \\
\text { (1 bibit) }\end{array}$ & $\begin{array}{c}\mathrm{j} 2 \\
\text { (2 bibit) }\end{array}$ & $\begin{array}{c}\mathrm{j} 3 \\
\text { (3 bibit) } \\
\end{array}$ & \\
\hline w1 (7 hari) & 1,58 & 3,58 & 2,33 & 2,50 \\
\hline w2 (14 hari) & 1,67 & 3,25 & 2,67 & 2,53 \\
\hline w3 (21 hari) & 1,42 & 3,08 & 0,75 & 1,75 \\
\hline Rata - rata & $1,56^{\mathrm{b}}$ & $3,31^{\mathrm{a}}$ & $1,92^{a b}$ & \\
\hline
\end{tabular}

Hal yang sama di ungkapkan Abdullah et al. (2000) di dalam Napisah dan Ningsih (2014) bahwa mutu bibit yang ditanam salah satunya dipengaruhi umur bibit dipersemaian sebelum ditanam. Penggunaan bibit padi yang berumur sekitar 30 hari akan memberikan hasil yang kurang baik, karena bibit yang digunakan relatif tua sehingga lambat untuk beradaptasi dengan lingkungan, mempunyai anakan yang tidak seragam, perakaran dangkal dan selanjutnya pertumbuhan tanaman kurang sempurna.

Sedangkan umur 21 hari sudah terpisah dari biji dan tidak mempunyai cadangan makanan lagi saat dilakukan pindah lapang. Hal ini mengakibatkan tanaman mengalami cekaman sejak hari pertama pindah lapang dan membutuhkan banyak energi pada masa pemulihan. Kondisi ini berpengaruh pada laju pertumbuhan vegetatif yang relatif lebih rendah. Tingkat laju pertumbuhan tanaman yang rendah akan menurunkan laju distribusi bahan kering dari daun ke biji (Masdar, 2006).

Umur bibit pindah lapang sangat berpengaruh terhadap produksi padi. Semakin cepat bibit pindah lapang akan semakin memadai periode bibit beradaptasi 
dengan lingkungan baru, sehingga semakin memadai periode untuk perkembangan anakan dan akar. Perakaran bibit berumur kurang dari 15 hari lebih cepat beradaptasi dan cepat pulih dari cekaman akibat dipindahkan dari persemaian ke lahan pertanaman (BPTP Jambi, 2009 dalam Fita Anggraini, dkk, 2013). Sejalan dengan pendapat Gani (2003) menyatakan bahwa penggunaan bibit padi sawah dengan umur yang relative muda (umur 12-15 HSS) akan membentuk anakan baru yang lebih seragam ada aktif serta berkembang lebih baik karena bibit yang lebih muda mampu beradaptasi dengan lingkungan yang baru setelah tanaman dipindah.

Hal ini sesuai pendapat Hermawati (2009), pertumbuhan akar yang bebas hanya mungkin terjadi pada akar bibit muda yang punya banyak ruang dan oksigen, bahkan saat air dan nutrisi kurang tersedia tanaman dapat memperpanjang akarnya.

Penggunaan bibit tanaman padi umur muda menyebabkan bibit tersebut lebih cepat beradaptasi dengan lingkungan tumbuh, mempunyai perakaran yang lebih baik, sehingga lebih efektif memanfaatkan hara dan dapat tumbuh lebih baik. Jika kondisi sistem perakaran tanaman padi terganggu akibat proses pindah tanam padi dari persemaian ke lahan tanam, maka akar tidak akan berfungsi sebagaimana mestinya.

Sedangkan umur menjelang panen tinggi tanaman tidak lagi dipengaruhi oleh umur bibit dan lebih tergantung pada faktor genetis sehingga tinggi tanaman antar perlakuan hampir sama (Hermawati 2009). Erihan, et al (2012) juga menemukan bahwa perlakuan umur bibit memberikan pengaruh tidak nyata terhadap jumlah anakan produktif tanaman dan Berat Gabah Kering Panen.

Tinggi rendahnya berat biji tergantung dari banyak tidaknya bahan kering yang terkandung dalam biji. Bahan kering dalam biji diperoleh dari fotosintesis yang selanjutnya dapat digunakan untuk pengisian biji sesuai dengan pendapat Rahimi (2011) yang menyatakan bahwa rata-rata bobot biji sangat ditentukan oleh bentuk dan ukuran biji pada suatu varietas. Apabila tidak terjadinya perbedaan ukuran biji maka yang berperan adalah faktor genetik.

\subsection{Uji Pengaruh Jumlah Bibit Pada} Pertumbuhan dan Hasil Tanaman Padi

Berdasarkan sidik ragam perlakuan umur pemindahan berpengaruh tidak nyata pada pengukuran tinggi tanaman padi pada umur 2, 4 dan 6 minggu setelah tanam, jumlah anakan total 6 minggu setelah tanam, Ratarata jumlah cabang malai perumpun, rata-rata panjang malai, rata-rata jumlah gabah isi permalai, rata-rata jumlah gabah hampa permalai, rata-rata jumlah gabah permalai, rata-rata berat gabah basah perumpun dan rata-rata berat gabah kering giling. diduga akibat faktor genetik dan lingkungan (hama). Sejalan dengan pendapat Rahmat Hidayah, Jurnawaty Sofjan dan Wardati (2016), faktor genetik berkaitan dengan kemampuan tanaman padi mengoptimalkan produksi dalam pengisian biji dengan mengalokasikan hasil fotosintesa secara tepat, sedangkan faktor lingkungan berhubungan dengan kelancaran proses fotosintesa.

Jumlah bibit tidak menjadi faktor penentu pertumbuhan anakan dan produksi tanaman, namun tergantung pada seberapa besar jumah tanaman dapat tumbuh dan mengeluarkan malai per rumpun dimana nantinya akan mempengaruhi hasil yang didapatkan dari tanaman itu sendiri. Husnah (2010) menyatakan bahwa anakan produktif merupakan anakan yang berkembang lebih lanjut dan menghasilkan malai, tanaman padi potensi pembentukan anakan produktif terlihat dari jumlah anakan, tetapi tidak selamanya demikian karena pembentukan anakan dipengaruhi oleh lingkunganya.

Tabel 3. Pengaruh Umur Pemindahan dan Jumlah Bibit Terhadap Rata-rata Jumlah Anakan Total (rumpun) Tanaman Padi 2 MST

\begin{tabular}{|c|c|c|c|c|}
\hline \multirow{2}{*}{$\begin{array}{c}\text { Umur } \\
\text { Pemindahan } \\
(\mathrm{W}) \\
\end{array}$} & \multicolumn{3}{|c|}{ jumlah Bibit ( $\mathrm{J}$ ) } & \multirow{2}{*}{$\begin{array}{l}\text { Rata } \\
\text { rata }\end{array}$} \\
\hline & $\begin{array}{c}\mathrm{j} 1 \\
(1 \mathrm{bibit})\end{array}$ & $\begin{array}{c}\mathrm{j} 2 \\
(2 \mathrm{bibit})\end{array}$ & $\begin{array}{c}\mathrm{j} 3 \\
\text { (3 bibit) }\end{array}$ & \\
\hline w1 (7 hari) & 11,25 & 12,17 & 13,17 & 12,19 \\
\hline w2 (14 hari) & 7,58 & 18,08 & 13,83 & 13,17 \\
\hline w3 (21 hari) & 10,25 & 12,75 & 11,50 & 11,50 \\
\hline Rata - rata & $9,69^{\mathrm{b}}$ & $14,33^{\mathrm{a}}$ & $12,83^{\mathrm{ab}}$ & \\
\hline
\end{tabular}

Menurut Dachban dan Dibisono (2010), bertambahnya jumlah bibit per titik tanam, cenderung meningkatkan persaingan tanaman, baik antara tanaman dalam satu rumpun maupun antar Laju tumbuh tanaman (LTT).

Berdasarkan hasil analisa sidik ragam bahwa jumlah bibit (J) berpengaruh sangat nyata terhadap rata-rata jumlah anakan total 2,4 minggu setelah tanam dan ratarata berat 1000 biji gabah pada perlakuan jumlah 2 bibit (j2) memberikan hasil anakan yang lebih bnyak di bandingkan dengan perlakuan lainnya. sejalan dengan Atman (2007), menjelaskan, bahwa penanaman bibit dengan jumlah yang relatif lebih banyak menyebabkan terjadinya persaingan sesama tanaman padi (kompetisi inter spesies) yang sangat keras untuk mendapatkan air, unsur hara, $\mathrm{CO} 2, \mathrm{O} 2$, cahaya dan ruang untuk tumbuh, sehingga pertumbuhan akan menjadi tidak normal. Akibatnya, tanaman padi menjadi lemah, mudah rebah, mudah terserang penyakit, dan keadaan tersebut dapat mengurangi hasil gabah.

Fase vegetatif tanaman tumbuh cepat sampai fase reproduktif kemudian semakin lambat memasuki fase pemasakan, Menurut Abdullah (2004). Selanjutnya Masdar (2006) menyatakan bahwa jumlah bibit per lubang tanam berpengaruh terhadap pertumbuhan dan Hasil Tanaman Padi (Oryza Sativa L.) Dengan Menggunakan Metode The System Rice Intensification karena secara langsung berhadapan dengan kompetisi antar tanaman dalam satu rumpun.

Pada dasarnya penggunaan bibit yang terlalu sedikit akan lebih baik untuk pertumbuhan tanaman karena lebih rendah persaingan dalam penyerapan unsur hara dibandingkan dengan penggunaan bibit yang terlalu banyak. Hal ini sejalan dengan pendapat (Uphoff, 2001 dalam M. Amin 2015) yang menyatakan bahwa sistem budidaya secara konvensional umumnya memakai 3 - 7 bibit per lubang tanam sehingga terjadi persaingan unsur hara serta ruang gerak untuk perkembangan akar dan 
anakan kurang stabil yang pada akhirnya produktivitas rendah. Susilo dkk, (2015), menyebutkan, bahwa faktor jumlah bibit per lubang tanam berpengaruh nyata terhadap jumlah anakan dan berat 1000 biji gabah, tetapi berpengaruh tidak nyata pada variabel pengamatan lainnya.

Selain itu untuk mendapatkan tingkat produksi yang optimal, bibit merupakan salah satu komponen teknologi yang sangat berpengaruh. Bibit juga merupakan tumbuhan muda yang sangat menentukan untuk pertumbuhan tanaman selanjutnya. Salah satu upaya untuk mencapai sasaran tersebut diatas adalah melalui program intensifikasi dengan menerapkan teknologi produksi yang tepat serta penggunaan sarana produksi yang efesien dan menguntungkan, diantaranya adalah teknologi pemakaian jumlah bibit per rumpunnya (Gani, 2003).

\subsection{Interaksi Antara Umur Pemindahan dan Jumlah Bibit Terhadap Pertumbuhan dan Hasil tanaman Padi}

Interaksi Pengaruh Umur Pemindahan dan Jumlah Bibit Terhadap Pertumbuhan dan Hasil Tanaman Padi Sawah Perlakuan interaksi menunjukkan semua pengamatan menunjukkan berpengaruh tidak nyata, adapun penyebab yaitu di pengaruhi oleh faktor lingkungan (hama belalang, walang sangit dan burung pipit), tingginya serangan hama di akhir penelitian, yang mengakibatkan tingginya hasil panen yang hilang sehingga interaksi keduanya membawa pengaruh tidak nyata.

\section{Kesimpulan}

Berdasarkan hasil dan pembahasan penelitian ini dapat disimpulkan sebagai berikut :

Berdasarkan Hasil Penelitian Pengaruh Umur Pemindahan Serta Jumlah Bibit Pada Pertumbuhan dan Hasil Tanaman Padi (Oriza sativa L.) dapat di ambil beberapa kesimpulan sebagai berikut :

1. Perlakuan pengaruh umur pemindahan (W) menunjukkan tidak membawah pengaruh nyata pada perhitungan semua pengamatan.

2. Perlakuan jumlah bibit $(\mathrm{J})$ berpengaruh sangat nyata pada perhitungan jumlah anakan total pada umur 2 minggu setelah tanam, umur 4 minggu setelah tanam dan berat 1000 biji gabah. Sedangkan jumlah bibit yang menggunakan 3 taraf namun yang dominan berpengaruh yaitu jumlah anakan total dan berat 1000 biji gabah pada perlakuan 2 bibit (j2).

3. Sedangkan intraksi perlakuan pengaruh umur pemindahan serta jumlah bibit tidak membawa pengaruh nyata semua parameter pengamatan dari awal hingga pengamatan akhir.

\section{Daftar Pustaka}

Abdullah,s. 2004. Pengaruh perbedaan jumlah dan umur bibit terhadap pertumbuhan dan hasil padi sawah. Dalam lamid , Z., et al. (penyunting). Prosiding nasional penerapan agroinovasi mendukung ketahanan pangan dan agribisnis. Sukarami 10-11 agustus 2014. Kota Palembang. Sumatra Selatan.

Alfandi1, Dukat2 dan Elon Hermawan3.2016. Pengaruh Pengaturan Jarak Tanam dan Umur Bibit Terhadap Pertumbuhan dan Hasil Tanaman Padi (Oryza sativa L.) Kultivar Mekongga. Agroteknologi Fakultas Pertanian Universitas Swadaya Gunung Jati. Cirebon Jawa Barat.

Dachban dan Dibisono. 2010. Pengaruh sistem tanam, varietas jumlah bibit terhadap pertumbuhan dan hasil padi sawah (Oriza sativa L.). Jurnal Ilmiah Pendidikan Tinggi. Sumatra Utara

Dinas Pertanian. 2017. Luas panen dan produksi padi dan palawija Kabupaten Paser. Tanah Grogot.

Erihan. M. Faridhan ,Radiandan Nurjani. 2012. Pengaruh Umur Bibit Terhadap Pertumbuhan dan Hasil Tanaman Padi Varietas Inpara 3 Dengan Metode SRI Pada Tanah Aluvial. Pontianak.

Fita Anggraini1, Agus Suryanto, Nurul Aini. 2013. Istem Tanam dan Umur Bibit Pada Tanaman Padi Sawah (Oryza sativa L.) Varietas Inpari 13. Jurusan Budidaya Pertanian Fakultas Pertanian Universitas Brawijaya Jln. Veteran, Malang 66514, Indonesia.

Galih Angga Kusuma. 2015. Optimasi Pemupukan Nitrogen (N) dan Jumlah Bibit Pada Padi Tipe Baru Varietas IPB 3S. Departemen Agronomi dan Hortikultura Fakultas Pertanian Institut Pertanian Bogor. Bogor.

Gani, A. 2003. Sistem Intensifikasi Padi (system of rice intensification). Pedoman Praktis Bercocok Tanam Padi Sawah dengan Sistem SRI; $6 \mathrm{hlm}$. BPTPH Provinsi Jawa Barat.

Hasrizart, I. 2008. Pertumbuhan dan Produksi Beberapa Varietas Padi Sawah (Oryza sativa L) Pada Persiapan Tanah dan Jumlah Bibit yang Berbeda. Universitas Sumatra Utara. Medan.

Hermawati T. 2009. Keragaman padi varietas indragiri pada perbedaan umur bibit dengan metode SRI (system of rice intensification). Universitas Jambi.

Hesthiati dan Rawiniwati. 2012. Produksi Padi (Oryza Sativa L) Pada Jarak Tanam dan Jumlah Bibit Per Lubang Tanam Yang Berbeda Yang Ditanam Secara Organik Pada System Of Rice Intensification (Sri).

Husna, Y. 2010. Pengaruh Penggunaan Jarak Tanam Terhadap Pertumbuhan 1 Mahasiswa Fakultas Pertanian Universitas Riau 2 Dosen Fakultas Pertanian Universitas Riau JOM Faperta. Oktober 2015 dan Produksi Padi Sawah (Oryza sativa L.) Varietas IR 42 dengan Metode SRI (System of Rice 
Intensification). Jurnal Jurusan Agroteknik. Fakultas Pertanian. Universitas Riau.

I Nyoman Arnama. 2008. Pertumbuhan dan Produksi Dua Varietas Padi Sawah (Oryza sativa L.) Dengan Variasi Jumlah Bibit Per Rumpun. Program Studi Agroteknologi Sekolah Pascasarjana Universitas Hasanuddin.Makassar.

Joko Susilo, Ardian dan Erlida Ariani. 2015.Pengaruh Jumlah Bibit Per Lubang Tanam dan Dosis Pupuk N, P dan K Terhadap Pertum Buhan dan Produksi Padi Sawah (Oryza sativa L.) DENGAN METODE SRI. Jom Faperta. Jurusan Agrotegnologi. Fakultas Pertanian. Universitas Riau. Jln. HR. Sabrantas Pekanbaru

Mahrus Ali, Abdullah Hosir dan Nurlina. 2017. Perbedaan Jumlah Bibit per lubang Tanam Terhadap Pertumbuhan dan Hasil Tanaman Padi (Oryza sativa L.) Dengan Menggunakan Metode The System Rice Intensification. Program Studi Agroteknologi Fakultas Pertanian Universitas Merdeka Surabaya. Jl. Ketintang Madya No VII/2 Surabaya.

Masdar. 2006. Pengaruh Jumlah Bibit Per Titik Tanam dan Umur Bibit Terhadap Pertumbuhan Reproduktif Tanaman Padi pada Irigasi Tanpa Penggenangan. Jurnal Dinamika Pertanian. Universitas Bengkulu.

Mintono, Didit Riancono, Evi Yanti, Maqfi Dwi Cahyo. 2016. Produktivitas Padi (Oryza sativa L.) VAR IR-64 Menggunakan metode System of Rise Intensification (SRI) Dengan Beberapa Model Tanam (Tegel dan Legowo) dan Jumlah Bibit Per Lubang Tanam. Universitas Muhammadiyah Sidoarjo. Sidoarjo.

Mubiar Purwasasmita, Alik Sutaryat. 2012. Padi SRI Organik Indonesia. Penebar Swadaya. Jakarta.

Napisah.K dan Ningsih.D.R. 2014. Pengaruh Umur Bibit Terhadap Produktivitas Padi Varietas Inpari 17. Balai Pengkajian Teknologi Pertanian (BPTP), Banjar Baru. Kalimantan Selatan.

Ridwan dan munir. 2002. Pengaruh Umur Bibit Pada Padi Sawah Pada System Tanam Pindah. Dalam Las, I, Et Al. (Penyunting). Prosiding Seminar Nasional Dalam Ketahanan Pangan dan Agribisnis 21-22 November, Padang.

Rahimi, Z. Zuhry, E. Nurbaiti. 2011. Pengaruh Jarak Tanam Terhadap Pertumbuhan dan Produksi Padi Sawah (Oryza sativa L.) Varietas Batang Piaman dengan Metode System of Rice Intensification (SRI) di Padang Marpoyan Pekanbaru. Jurnal. Fakultas Pertanian. Universitas Riau.
Rahmat Hidayah, Jurnawaty Sofjan dan Wardati. 2016. Pengaruh Umur Bibit dan Pupuk N, P, K Terhadap Padi Varietas Ir 42 Di Lahan Pasang Surut Dengan Metode Sri Di Desa Kuala Mulya Kecamatan Kuala Cenaku. Rotechnology Departement. Agriculture Faculty. University of Riau J1. HR. Subrantas Km 12,5 Simpang Baru. Pekan Baru.

Sauki A; Nugroho A. dan Soelistiyono R. 2014. Pengaru Jarak Tanam dan waktu Penggenangan Pada Metode SRI (System of Rice Intensification) Terhadap Pertumbuhan dan Hasil Tanaman (Oryza sativa L.) Jurnal Produksi Tanaman.

W.D.Herawati. 2012. Budidaya Padi. Perpustakaan Nasional. Jogjakarta. 